\section{Canada's science funding}

SIR-Your recent articles on "Science in Canada" (Nature 333, 717; 1988) clearly identified our biggest problem as the very low funding of research, and particularly industrial research and development, where we suffer from the branch plant nature of much of our industry. Why should a company carry out research and development at a subsidiary in Canada if it can do it more cheaply or conveniently at the parent plant in Chicago or Los Angeles? This problem is likely to become even worse if the so-called free trade agreement between Canada and the United States becomes law.

For many years, federal governments have recognized that Canadian science is seriously underfunded, and have promised remedial measures to bring the spending up to some figure, usually around 2.5 per cent of gross national product, within a few years. Results have, however, been negligible. The present government is no better than its predecessors; in fact, it may be worse, if only because it promises more, but with no more results. For example, the Prime Minister announced last winter that the government would spend an additional $\$ 1,300$ million on science and technology in the next five years. In fact, as pointed out by Bill Rompkey, MP (Canadian Research/Biotechnology Canada, Winter 1988), every dollar can be accounted for by cuts made elsewhere in science-related spending. The recent announcement that much of this money will be reserved for work related to the US space station may, in fact, mean less money available for other areas of science than now.

With respect to McGill University, I wish to make two points, one an interpretation of your figures and the other a correction. In your table on p. 723 , you report federal research and development income for ten universities. To understand these figures, the sizes of the universities should have been included. For example, the University of Toronto received by far the largest amount (12.3 per cent), and is well recognized as running the largest research operation. McGill follows, with 8.6 per cent. However, when one takes into account that Toronto is twice the size of McGill, the figures take on a different significance. In fact, last year it was reported that, among Canadian universities, McGill was first in terms of research grants per staff, graduate students per staff and graduate degrees granted per staff. The second point, a correction, relates to the statements on p. 730 . You refer to "... McGill University ... now one of Canada's best known and wealthiest universities", and appear to draw a contrast by stating "The Université de Montréal has come through some difficult times, hit by the economic depression of the early 1980 s ....". There was a time when McGill was relatively wealthy. However, after many years of chronic underfunding (according to its own formula, Quebec's Department of Education calculates that McGill is underfunded by about $\$ 20$ million per year), its free endowments have been exhausted to finance current operations. Reporting in April on improvements in Quebec university finances, Education Minister Ryan announced that with the exception of Concordia and McGill Universities and l'Ecole des Hautes Etudes Commerciales, which remain in a difficult financial situation, Quebec universities - the universities of Montreal, Sherbrooke, Laval and Quebec and Bishop's University - have attained financial equilibrium. Because in politics perception is more important than fact, your labelling of McGill University as "wealthy" helps to perpetuate a myth that reduces our chances of fair treatment even from the best-intentioned government.

Department of Biology,

E.R. BOOTHROYD

McGill University,

Montreal, PQ, Canada H3A $1 B 1$

\section{Graduate salaries}

SIR-In the article "Degrees of salary and satisfaction" (Nature 334, 393; 1988), Jim Taylor draws attention to the comparatively low average salary for biochemists during their first six years in the job market compared to other science graduates, especially those in mathematics, computing and engineering.

Although later in the article the author states that ". . . the proportion of graduates obtaining further qualifications after their graduation is uncorrelated with their salary levels . . .", it is difficult to see how this can be so. From information in the same table, we see that 87 per cent of biochemists obtained postgraduate qualifications - a higher proportion than in any of the other sciences surveyed. Surely this means that for three to four years of their potential period of employment, most of these graduates will have been PhD students with a grant of $£ 2,975$ a year at current rates ( $£ 3,630$ in London). This must have the effect of drastically depressing the average salaries obtained by these graduates in their first years of employment, placing them at an apparent disadvantage compared to their peers who went straight into employment after graduation.

The Biochemical Society,

H.M. KEIR

7 Warwick Court, High Holborn,

London WCIR SDP, UK

\section{UK science teaching}

SIR-I am a practising science teacher and have some sympathy with the views of M.H. Dodson (Nature 333, 9; 1988). I was, however, surprised by the letter from Geoff Hayward and Martin Hollins (Nature 333, 698; 1988), which seemed to be attacking comments that had not been made. (Perhaps this is why Hayward and Hollins used the word 'myths' to describe these non-existent statements.)

Like good teachers, they organize their comments "First, he says . . ." followed by a statement that Dodson did not make about education at school being "merely an apprenticeship for the real education that they will receive once they reach university". Undoubtedly there are people who hold such views, but Dodson's letter does not suggest that he does. And in any case, is it not true that ' $A$ ' levels are "an apprenticeship" to other things, whether they are university studies, working in an estate agents, or being a policeman?

The second criticism of Dodson by Hayward and Hollins concerns standards. They refute his 'suggestion' that the standards of science education are high. "By any criterion this is simply not true", they say. But I take the term 'standards' in the sense that Dodson uses it in the final paragraph of his letter to mean something about the level of academic attainment. Hayward and Hollins seem to be using it as a measure of how good the process of teaching is. The confusion over the terms used may mean that each is correct.

I agree with Hayward and Hollins that "University entrance requirements have distorted the educational system for too long". But are they also saying that the standards of 'science education' are as they are (by implication, not very good) because of distortion resulting from the university entrance requirements?

If we pose the question "What is formal education for?", there will be a number of answers. Some will apply to all pupils, while others will apply to relatively few pupils. Dodson's fears about 'integrated science' are concerned with one of the acknowledged aims of formal education. Arthur J. Kahn's letter (Nature 334, 466; 1988) makes it very clear what many science teachers fear about integrated science'. Hayward and Hollins seem to be concerned with a different aim. The sooner we all realize that formal education attempts to fulfil several roles the better.

Finally, their letter seems to illustrate what is wrong with so much public debate in the United Kingdom. The debate seems to be absent; what remains is statement of views with scant regard to what the "opposition' has actually said.

20 Church Drive,

Roland Dixon

West Buckland, Wellington,

Somerset TA21 9LZ, UK 